\title{
Modeling the Increase of Floodwater Level at the Junction of the Batang Suliti and Batang Bangko Rivers in Sungai Pagu Sub-District, Muaro Labuh City, Solok Selatan District Using HEC-RAS 4.0
}

\author{
Febriza $^{1}$, Junaidi ${ }^{2}$, Ir. Ahmad Junaidi ${ }^{3}$ \\ ${ }^{1}$ Post Graduate Student of Civil Engineering Department, Faculty of Engineering, Andalas University, Indonesia \\ ${ }^{2}$ Lecturer in The Civil Engineering Department, Faculty of Engineering, Andalas University, Indonesia \\ ${ }^{3}$ Lecturer in The Civil Engineering Department, Faculty of Engineering, Andalas University, Indonesia
}

\begin{abstract}
Flood is a common natural disaster, especially in Indonesia, and causes a huge amount of material and social loss. West Sumatera is one of the provinces that is often affected by flooding, and one of the most affected area is Solok Selatan District. In this district, there is a junction of two watersheds that often affected by floods, which are Batang Suliti watershed and Batang Bangko watershed. The junction of the Batang Suliti river and Batang Bangko river is in Sungai Pagu Sub-District. One example of a huge flood occurred on February 8, 2016 where the rain occurred for 17 hours long which caused a $0.5-3 \mathrm{~m}$ deep of flood inundation and covering $11.9 \mathrm{~km}^{2}$ area. Hence, it is necessary to know how much is the capacity of the river's cross-sections to accommodate the water flow before runoff discharge occurs. In this study, we calculate the runoff discharge using HEC-RAS 4.0 software and $Q_{25}$ discharge which are $332.42 \mathrm{~m}^{3} / \mathrm{s}$ for the Batang Suliti river and $336.43 \mathrm{~m}^{3} / \mathrm{s}$ for the Batang Bangko river.
\end{abstract}

Keywords:- Batang Bangko; Batang Suliti; Flood; HECRAS.

\section{INTRODUCTION}

Flood is a common natural disaster, especially in Indonesia. It causes material and social losses. West Sumatera is one of the provinces that is often affected by flood event which supported by a relatively high rainfall intensity and consequently increases the flood risk. One of the most affected area is Solok Selatan District. This district is located in the Bukit Barisan mountain range, which is the part of the Patahan Semangka area. Solok Selatan District has two watershed areas located in Sungai Pagu Sub-District, which is Batang Suliti watershed with $249.81 \mathrm{~km}^{2}$ area and $30.79 \mathrm{~km}$ of river length. The other one is Batang Bangko watershed which has a $249.81 \mathrm{~km}^{2}$ area and $27.3 \mathrm{~km}$ of river length.

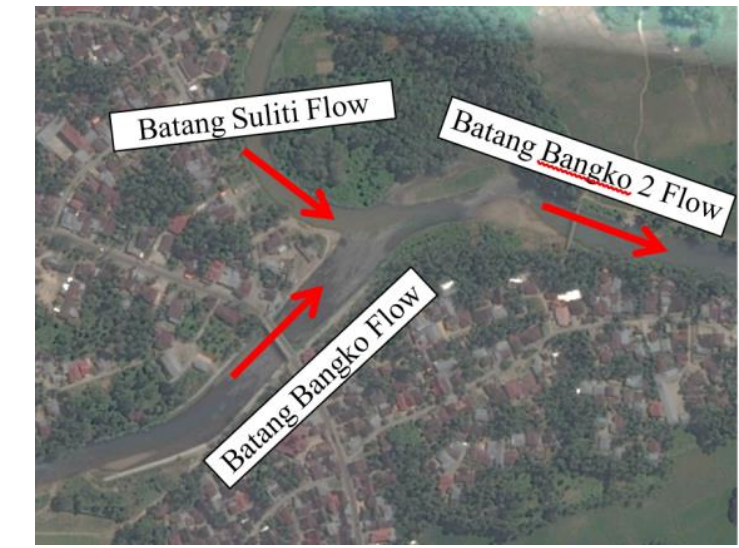

Fig 1:- The Junction of the Batang Bangko and Batang Suliti Rivers

Muara Labuh City is located in Sungai Pagu SubDistrict and has a high population density. Thus, an understanding of flood mitigation is important in this area. An intense flood in this area occurred on February 8, 2016, where heavy rainfall was occurred for about 17 hours and caused a flood inundation with $0.5-3 \mathrm{~m}$ deep and covered a $11.9 \mathrm{~km}^{2}$ of affected area.

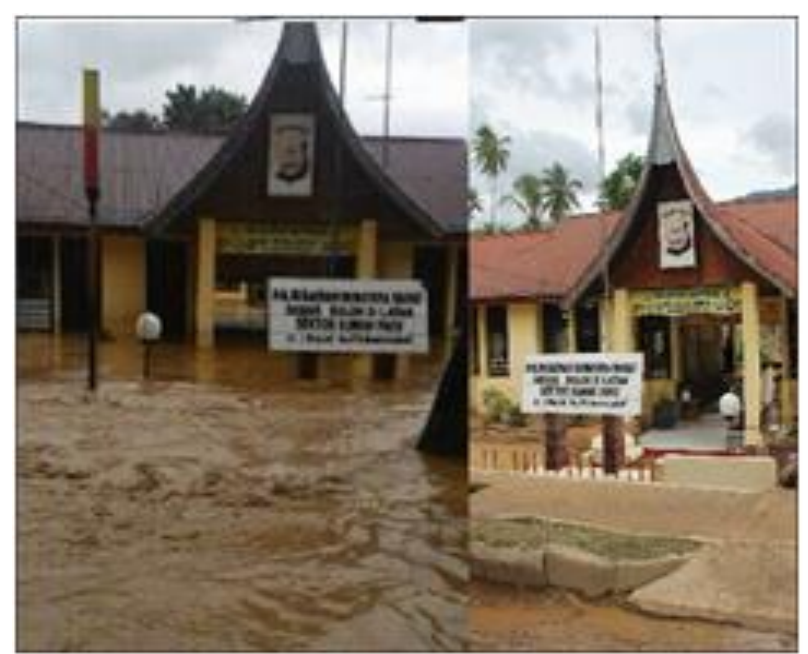

Fig 2:- Flood in Solok Selatan Police Station 
ISSN No:-2456-2165

This study modeled the Batang Suliti river and Batang Bangko river flow for a flood with a $\mathrm{Q}_{25}$ return period discharge as the reference to prepare the alternatives of flood control effort at Batang Suliti and Batang Bangko Rivers by a structural approach, that can hopefully reduce the impact and loss caused by the flood at Sungai Pagu Sub-District, Muaro Labuh City.

\section{LITERATURE REVIEW}

Waskito (2012) evaluated the flood control for the Cibeet River in Bekasi District in Indonesia [1]. The method involved obtaining the rainfall and flood discharge for a specific return period and hydraulic modeling simulations with HEC-RAS software to determine the capacity of the river channel and the profile of the floodwater level for a certain return period based on the flood discharge. The results showed that normalization/excavation of the upstream and downstream channel was able to safely drain the discharge for a return period of 25 years $\left(Q_{25}\right)$, so this mitigating activity was recommended for the medium term.

Muin, Sisi Febriyanti et al. (2015), conducted flood modeling and analysis of losses due to flood disaster in the upstream region of the Citarum watershed [2]. This research determined the return period of the discharge using the Hydrognomon software (free software with a GNU GPLv3 license). The Hydrognomon software has been developed to process hydrology data for data series. In this research, the data distribution was limited to three: Gamma, Pearson III (Al-Mashidani et al. 1978; Saeideslamian and Husseinfeizi 2007; Mujiburrehman 2013) and Normal (Mujiburrehman 2013).

\section{A. Hydrological Analysis}

We used the Thiessen polygon method for the closest rain station. The normal, Gumbel, and log Person type 3 distributions were used to determine the rain distribution. Nakayasu Unit Hydrograph calculation were used to determine the peak flood discharge with the following formula (see Figure 3):

$Q_{p}=\frac{C \cdot A \cdot R_{0}}{3,6\left(0.3 \times T_{p}+T_{0.3}\right)}$

where:

$\mathrm{Q}_{\mathrm{p}}$ is the flood peak discharge $\left(\mathrm{m}^{3} / \mathrm{sec}\right)$

$\mathrm{R}_{\mathrm{o}}$ is the unit rain (mm)

$T_{p}$ is the time lag from the beginning of the rain to the peak of the flood (hour)

$\mathrm{T}_{0.3}$ is the time required for the decrease in discharge, from the peak to $30 \%$ of the peak discharge

$\mathrm{A}$ is the catchment area

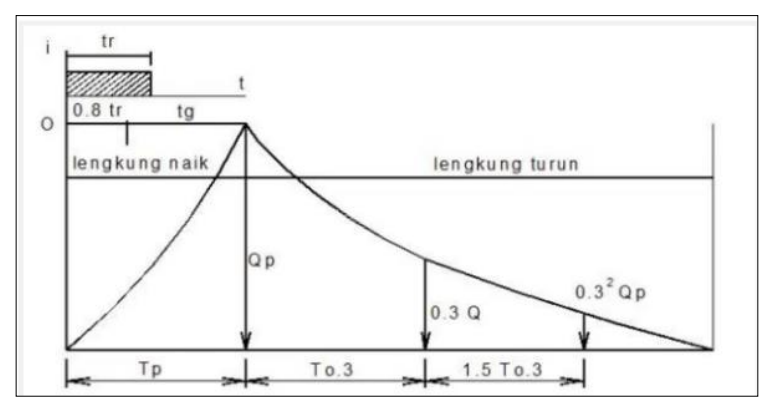

Fig 3:- Nakayasu Unit Hydrograph Method

\section{B. HEC-RAS Modelling}

The HEC-RAS program can be used to model both steady and unsteady flow simulations equipped with an analysis of sediment transport and water quality (temperature). HEC-RAS is a program with a graphical user interface that allows hydrological analysis, data management and storage, graphics, and reporting features [3]. The analysis of existing cross-sections with HEC-RAS determines the actual condition of a river by finding the profile of the water level during a flood. This study used permanent flow simulations because we only wanted to estimate the water level of the flood.

The water level was determined using the energy equation, which was solved with the standard step method. The energy equation between two cross-sections is:

$\mathrm{Y}_{2}+\mathrm{Z}_{2}+\frac{\alpha_{2} \mathrm{~V}_{2}^{2}}{2 \mathrm{~g}}=\mathrm{Y}_{1}+\mathrm{z}_{1}+\frac{\alpha_{1} \mathrm{~V}_{1}^{2}}{2 \mathrm{~g}}+\mathrm{h}_{\mathrm{e}}$

where:

$\mathrm{Y}_{1}, \mathrm{Y}_{2}$ is the flow depth (m)

$\mathrm{Z}_{1}, \mathrm{Z}_{2}$ is the channel base elevation $(\mathrm{m})$

$\mathrm{V}_{1}, \mathrm{~V}_{2}$ is the average speed $(\mathrm{m} / \mathrm{sec})$

$\alpha_{1}, \alpha_{2}$ is the coefficient of velocity

$\mathrm{g}$ is the gravitational acceleration $\left(\mathrm{m} / \mathrm{sec}^{2}\right)$

$\mathrm{h}_{\mathrm{e}}$ is the head loss $(\mathrm{m})$

\section{Planning Standards of Flood Design}

In this study, the flood plan standard was recommended for the minimum return period (initial phase). One of the most widely used standard in Indonesia is the minimum return period for floods associated with floodwater, which can be seen in Table 1 .

\begin{tabular}{|c|c|}
\hline Building Type & $\begin{array}{c}\text { Design Flood } \\
\text { Return Period }\end{array}$ \\
\hline Weir in Large River & 100 \\
\hline Weir in Moderate River & 50 \\
\hline Weir in Small River & 25 \\
\hline Dike in Large River/Important Area & 25 \\
\hline $\begin{array}{c}\text { Dike in Large River/Less Important } \\
\text { Area }\end{array}$ & 10 \\
\hline Important Bridge and Road & 25 \\
\hline Less Important Bridge and Road & 10 \\
\hline
\end{tabular}

Table 1:- Planning Standards of Flood Design 
ISSN No:-2456-2165

\section{RESEARCH METHODOLOGY}

This study involved these following steps:

$>$ River cross section data were collected from the Regional Office of Sumatra River Region V

$>$ Collect the references from books, journal, and manual related to flood analysis using HEC-RAS v4.0 software. The record of flood event in research site also collected.

$>$ Carry out the hydrological calculation in each Watershed.

$>$ Calculate the design flood discharge using the Nakayasu Unit Hydrograph method.

$>$ Plan a design cross-section in the affected area using the existing water level.

\section{RESULT AND DISCUSSION}

\section{A. Hydrological Analysis}

\section{$>$ Rainfall Area}

Based on the distribution of the rainfall station closest to the Batang Bangko and Batang Suliti watersheds, three rainfall stations (PCH Sungai Ipuh, PCH Muara Laboh, and PCH Padang Aro) were identified. The method used in the station's influence is Polygon Thiessen.

\section{Analysis of Regional Rainfall Distribution}

Analysis of the regional rain distribution was used to obtain the amount of rainfall based on a specific return period (10 or 25 years). The Normal, Gumbel, Log Person Type 3 methods were used. We also used Chi-Square and Kolmogorov-Smirnov tests to determine the most appropriate method for the design rainfall. Based on the matching test results, the Gumbel method was chosen, see Table 2.

\begin{tabular}{|c|c|c|c|}
\hline \multicolumn{2}{|c|}{ Batang Bangko } & \multicolumn{2}{c|}{ Batang Suliti } \\
\hline $\mathrm{T}$ & $\mathrm{R}_{\operatorname{Tr}}$ & $\mathrm{T}$ & $\mathrm{R}_{\operatorname{Tr}}$ \\
\hline 2 & 71.76 & 2 & 81.16 \\
\hline 5 & 93.49 & 5 & 102.73 \\
\hline 10 & 107.88 & 10 & 117.01 \\
\hline 25 & 126.06 & 25 & 135.05 \\
\hline 50 & 139.54 & 50 & 148.44 \\
\hline 100 & 152.93 & 100 & 161.73 \\
\hline
\end{tabular}

Table 2:- Design Rainfall using Gumbel Method

\section{B. Design Flood Discharge}

In river planning, it is necessary to know the distribution of hourly rainfall within a certain interval to estimate the design flood hydrograph through the hydrograph unit. This research used the Nakayasu unit hydrograph method, see Figure 4.

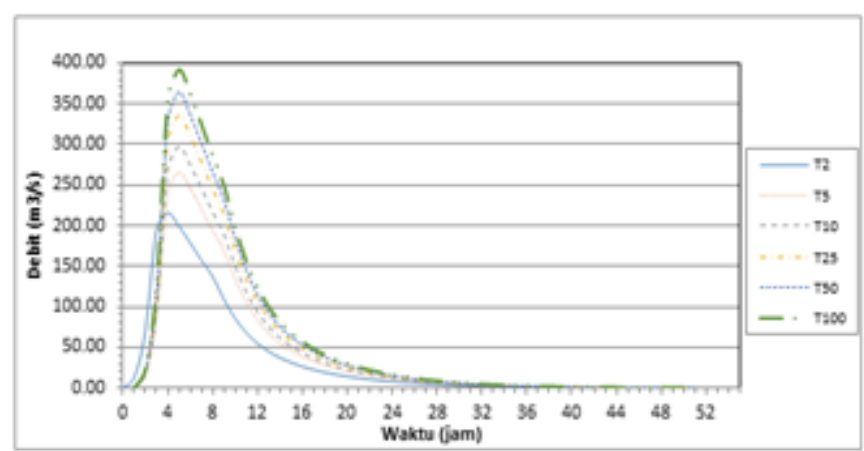

Fig 4:- Hydrograph of Batang Bangko Watershed

Based on the data analysis, the peak discharge in Batang Bangko for a 100 year return period is $392.52 \mathrm{~m}^{3} / \mathrm{s}$, and the peak discharge for a 25 year return period is 336.43 $\mathrm{m}^{3} / \mathrm{s}$, which used in this research (see Figure 4).

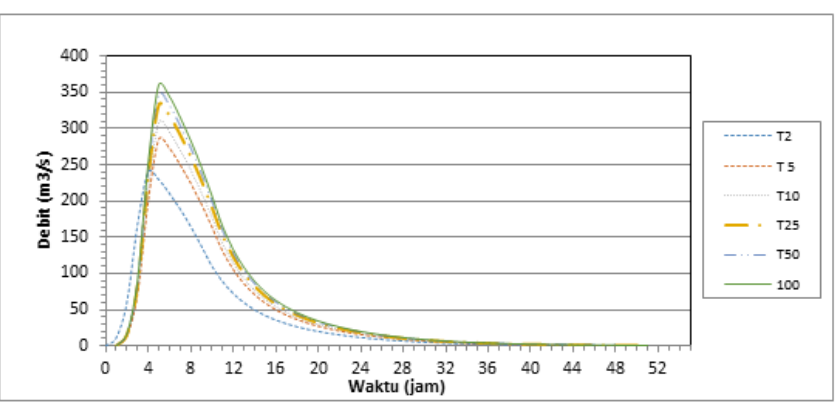

Fig 5:- Hydrograph of Batang Suliti Watershed

The data analysis was also carried out in Suliti Watershed, where $\mathrm{Q}_{100}\left(360.16 \mathrm{~m}^{3} / \mathrm{s}\right)$, and $\mathrm{Q}_{25}(332.42$ $\mathrm{m}^{3} / \mathrm{s}$ ) used for this research (see Figure 5). These values were used for the design discharge in flood modeling with HEC-RAS 4.0.

\section{Hydrological Analysis}

\section{HEC-RAS 4.0 Model}

HEC-RAS 4.0 was used for flood modelling using $\mathrm{Q}_{25}$ return period to obtained the height of design water level and the height of design dike in the cross-section prone to flooding. Figure 6 shows the Batang Bangko and Batang Suliti River network scheme, where The Batang Suliti River boils down into the Batang Bangko River. The river was divided into three parts:

- Batang Bangko River which located before the inflow of Batang Suliti (BK.12 to BK.1)

- Batang Suliti (ST.23 to ST.1)

- Batang Bangko after the inflow of Batang Suliti (BK2.44 to BK2.1) 




Fig 6:- Existing Trace of the Batang Bangko and Batang Suliti Rivers

\section{Modeling of Existing Cross-Section \\ $>$ Batang Bangko}

The analysis results for the existing condition of Batang Bangko River and Batang Suliti River in $\mathrm{Q}_{25}$ return period are as follow:

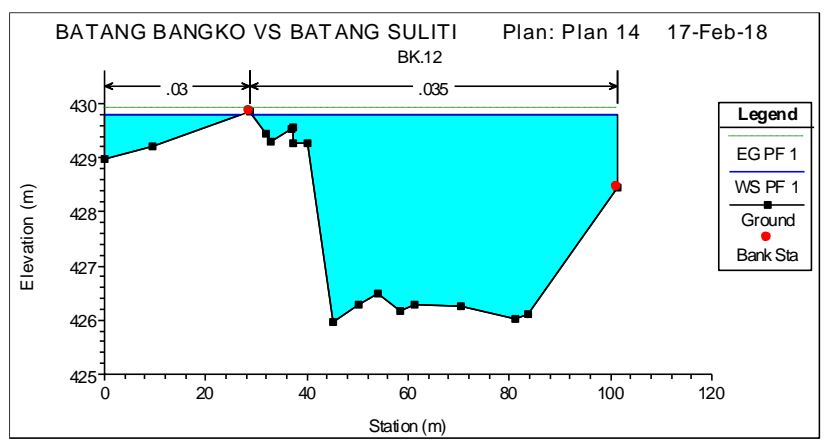

Fig 7:- Floodwater level of Batang Bangko (BK.12) for $\mathrm{Q}_{25}$

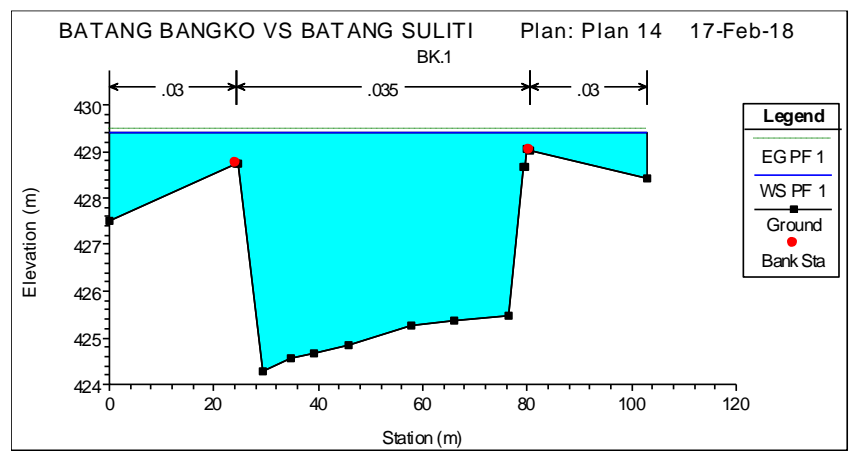

Fig 8:- Floodwater level of Batang Bangko (BK.1) for $\mathrm{Q}_{25}$

Figure 7 and Figure 8 show the flood simulation result for a 25 years of return period. Water level in BK 1 was increased for $0.2 \mathrm{~m}$ and $0.5 \mathrm{~m}$ for $\mathrm{BK} 1$ towards the left side of the bank station. The surface runoff occurred in all cross-sections of Batang Bangko (BK) River.
ISSN No:-2456-2165

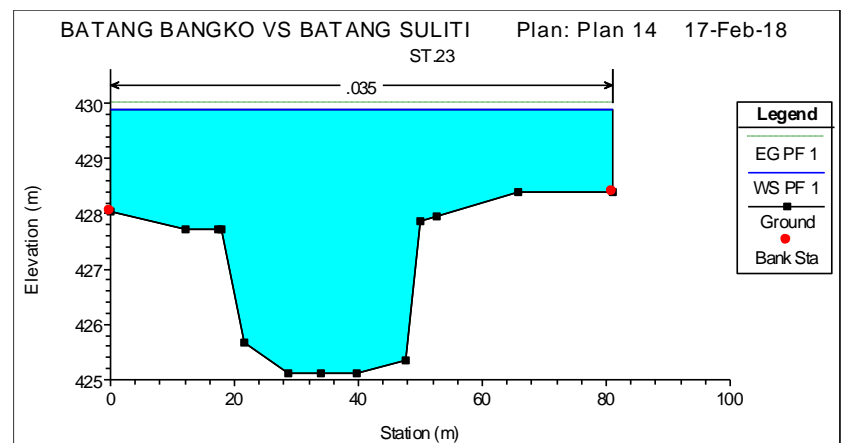

Fig 9:- Floodwater level of Batang Suliti River (ST 23) for $\mathrm{Q}_{25}$

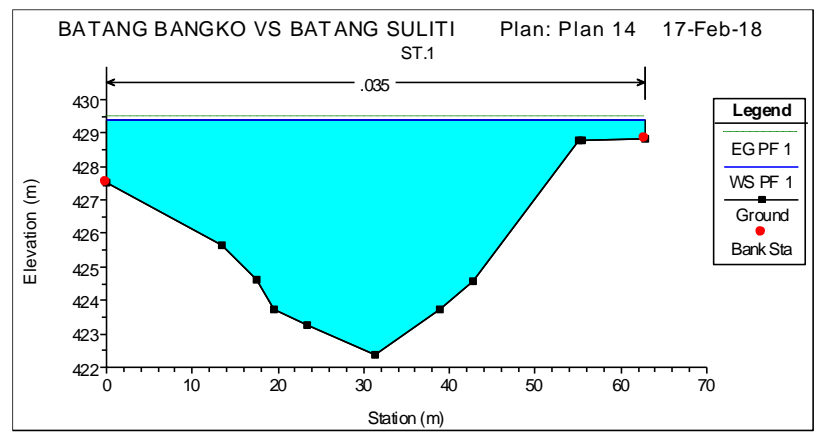

Fig 10:- Floodwater level of Batang Suliti River (ST 1) for $\mathrm{Q}_{25}$

In Batang Suliti River, an increase of floodwater level occurred in all of the cross-sections, (ST) except on the left side of ST 15, 14,13 and 12. The water level increased by 2 $\mathrm{m}$ for ST 23 and $2 \mathrm{~m}$ for ST 1 on the left side of the bank station.

For the Batang Bangko 2 River, runoff occurred after the junction of the Batang Suliti and Batang Bangko rivers (BK2.44 to BK2.1), except for the left side of the bank station for BK2.41 and BK2.15, and the right side of the bank station for BK2.11 and BK2.10. In BK2.3 to BK2.9 section, the river capacity is large enough to accommodate the 25 -year return period flow discharge.

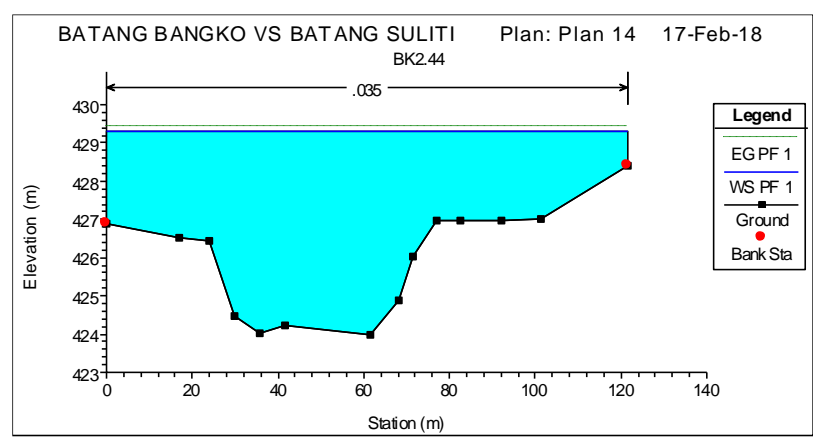

Fig 11:- Floodwater level of Batang Bangko 2 River (BK2.44) for $\mathrm{Q}_{25}$ 
ISSN No:-2456-2165

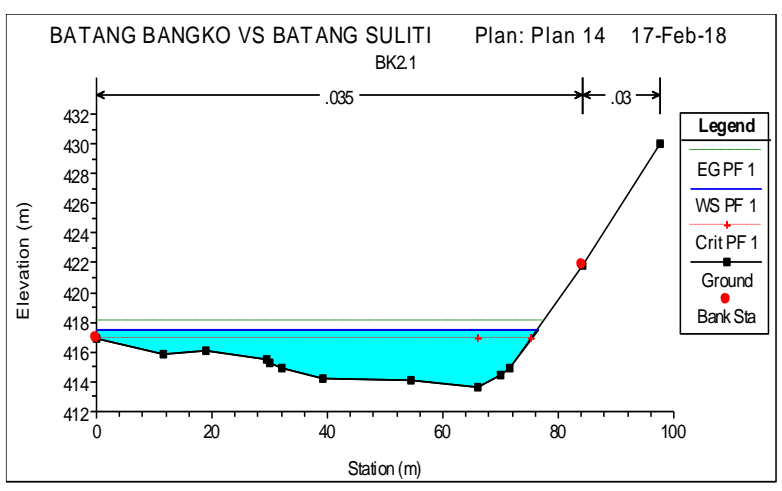

Fig 12:- Floodwater level of Batang Bangko 2 River (BK2.1) for $\mathrm{Q}_{25}$

Figures 13-15 show the water level profile of the Batang Suliti, Batang Bangko and Batang Bangko 2 rivers for $\mathrm{Q}_{25}$ return period. Some cross-sections did not overflow the river bank

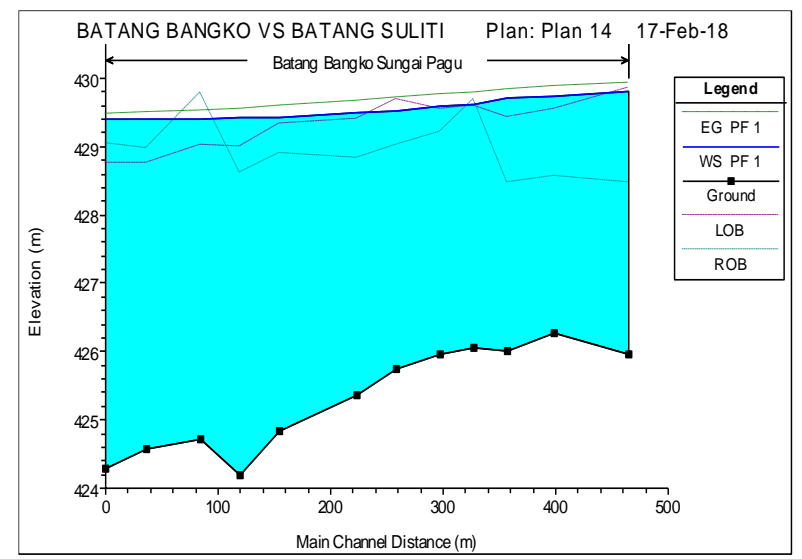

Fig 13:- Floodwater level profile of Batang Bangko River for $\mathrm{Q}_{25}$



Fig 14:-Floodwater level profile of Batang Suliti River for $\mathrm{Q}_{25}$

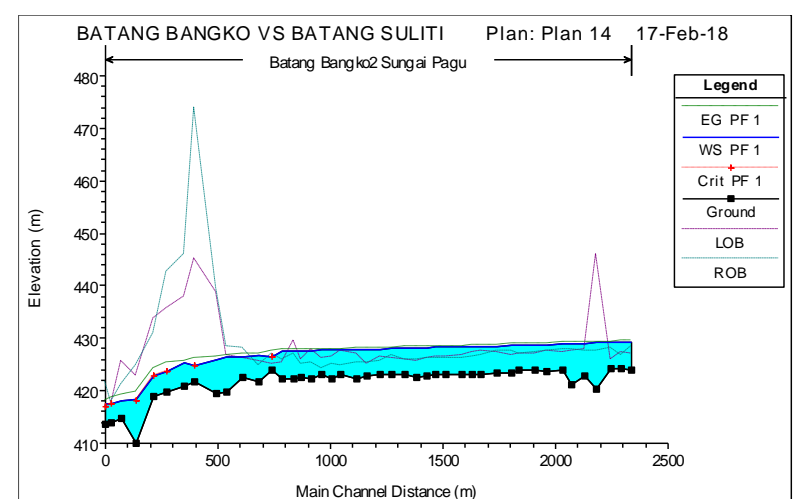

Fig 15:- Floodwater level profile of Batang Bangko 2 River for $\mathrm{Q}_{25}$

\section{E. Modeling of Design Cross-Section}

The simulation of design cross section was used to modeled the river cross-section and its flow to obtained the most suitable cross-section that could accommodate the flow capacity. The design cross-section with a trapezoidal double profile was used in this simulation. The lower crosssection was used to accommodate normal flow, while the upper cross-section accommodated the flood discharge. This analysis used the flood discharge for the 25-year return period.

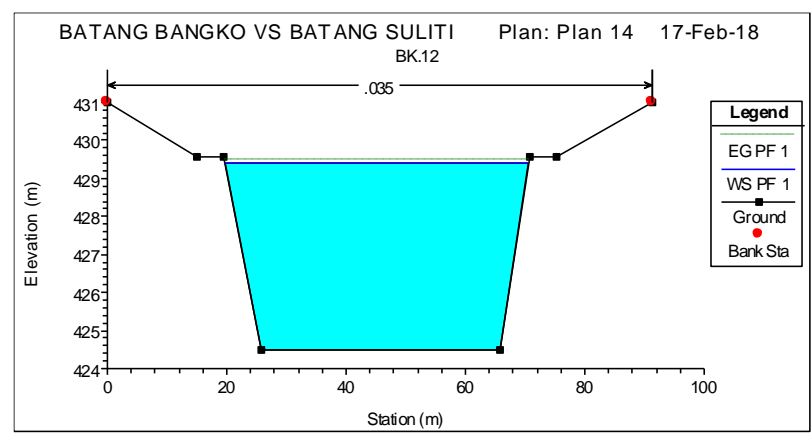

Fig 16:- Design Water Level of Batang Bangko River at BK.12 for $\mathrm{Q}_{25}$

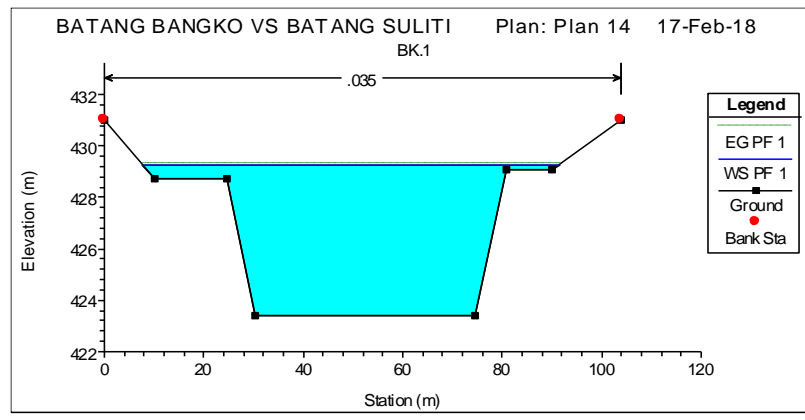

Fig17:- Design Water Level of Batang Bangko River at BK.1 for $\mathrm{Q}_{25}$

Figures 18 and 19 show the simulation results for the 25-year return period of Batang Suliti River. Based on the simulation, the design cross-section of Batang Suliti River can accomodate the flow capacity from ST.23 to ST.1 which located in the downstream of Batang Suliti River. 


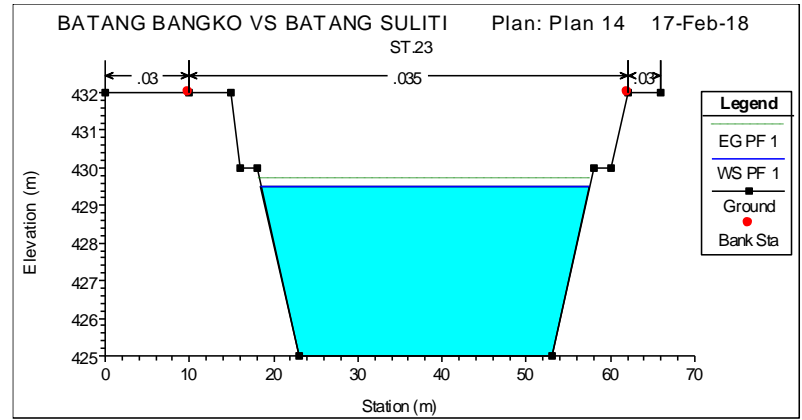

Fig 18:- Design Water Level of Batang Suliti River at ST.23 for $\mathrm{Q}_{25}$

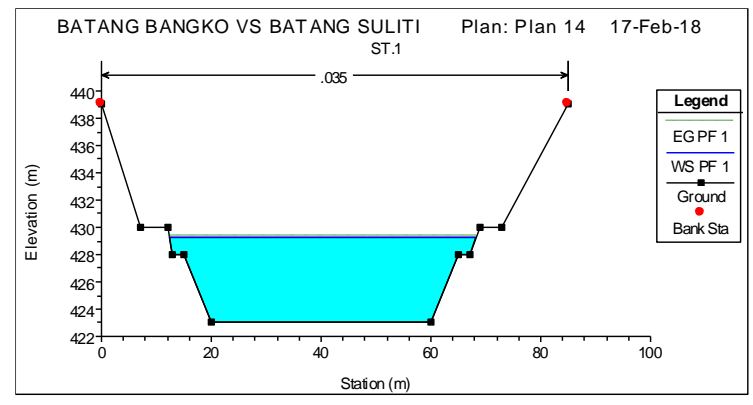

Fig 19:- Design Water Level of Batang Suliti at ST.1 for $\mathrm{Q}_{25}$

Figures 20 and 21 show similar findings in Batang Bangko 2 River after the simulation was carried out, where the cross-section is capable to accommodate the flow capacity.

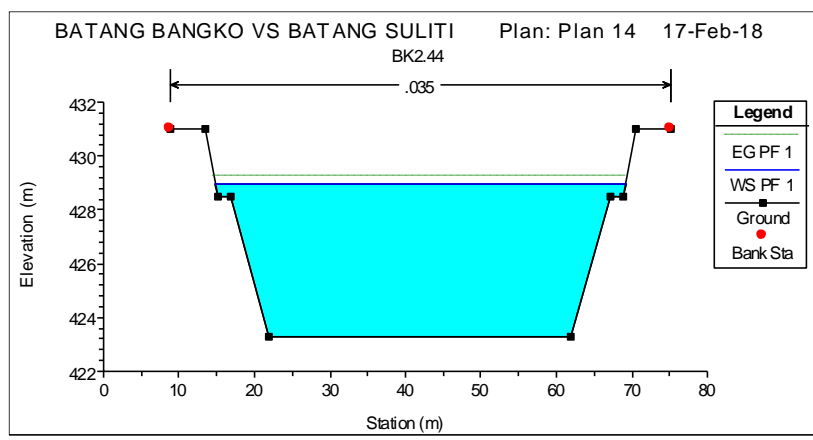

Fig 20:- Design Water Level of Batang Bangko 2 River at BK2.44 for $\mathrm{Q}_{25}$

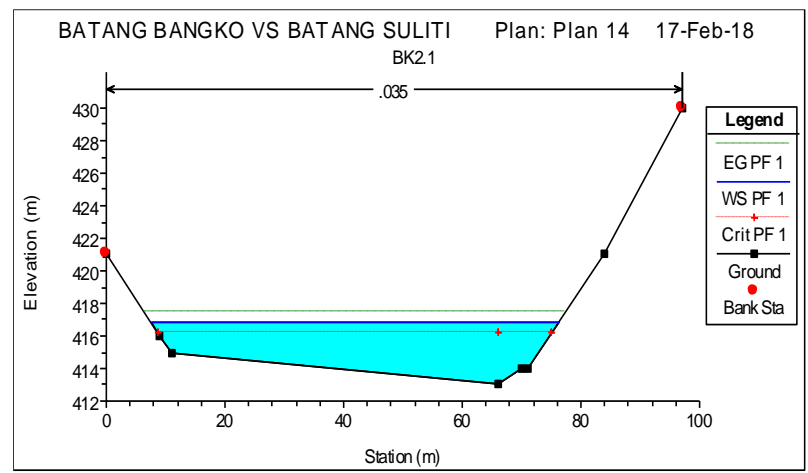

Fig 21:- Design Water Level of Batang Bangko 2 River at BK2.1 for $\mathrm{Q}_{25}$
After the junction of Batang Suliti and Batang Bangko rivers, the rivers widened to up to $40 \mathrm{~m}$. Based on the simulation using the design cross-section with double trapezoidal profile, the upstream of Batang Hari River is capable to accommodate the flow for the 25-year return period.



Fig 22:- Long Section of Design Water Level in Batang Bangko River for $\mathrm{Q}_{25}$

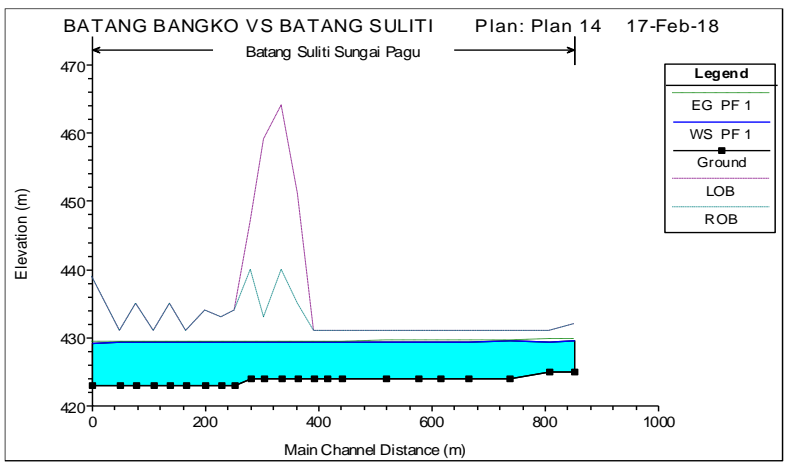

Fig 23:- Long Section of Design Water Level in Batang Suliti for $\mathrm{Q}_{25}$

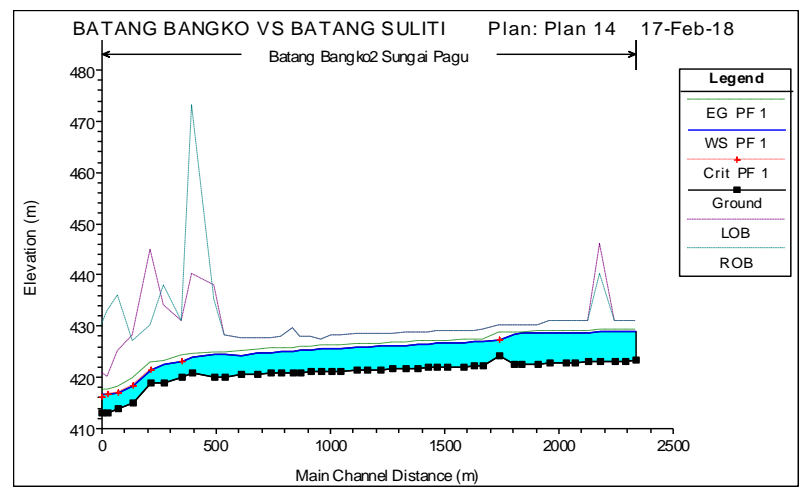

Fig 24:- Long Section of Design Water Level in Batang Bangko 2 River for $\mathrm{Q}_{25}$.

Figures 22 to Figure 24 show the profile of the water level along the Batang Bangko, Batang Suliti, and Batang Bangko 2 River for the 25-year discharge return period. Based on the model, it can be concluded that there is no runoff along the rivers. 


\section{CONCLUSIONS AND RECOMMENDATIONS}

\section{A. Conclusions}

Based on the research, it can be concluded that:

Batang Bangko and Batang Suliti Rivers are currently unable to accommodate the flood discharge for the 25year return period $\left(\mathrm{Q}_{25}\right)$ in the existing condition.

$>$ The simulation of the existing situation showed that most of the river sections were still able to accommodate the flood discharge up to 10 years of return period. However, in the study area at Muara Labuh City, Sungai Pagu Sub-district, Solok Selatan District, runoff start to occurred at the 25-year return period for the Batang Suliti River at ST 1-11 and 1623 cross-sections. The flood water also overflows from Batang Suliti river at ST.10 by $3.016 \mathrm{~m}$. This was similar to the flooding that occurred on February 8, 2016. In RS 12 cross section, the water overflowed by $0.33 \mathrm{~m}$. On the other hand, the downstream of Batang Bangko River at BK 1 was increased by $1.35 \mathrm{~m}$ towards the bank station.

Based on the current situation model, water level increased at ST.23 $(2.714 \mathrm{~m})$ and ST.1 by $3.089 \mathrm{~m}$ towards the bank station. The runoff occurred in almost of all cross-sections at the Batang Suliti River, except for ST.13 to ST.15 on the left side of the cliff, while the increase of flood water level occurred in all crosssections in Batang Bangko River.

$>$ After a simulation was carried out using the design cross-section, the result showed that there was no runoff along the Batang Bangko River, Batang Suliti River and Batang Bangko 2 River which shown from the water level modelling at long section profile for the 25-year return period.

\section{B. Recommendations}

Some recommendations that could be implemented are as follow:

$>$ A high permanent dike (poured with concrete) along the edge/side of the Batang Suliti River and Batang Bangko Rivers could be an alternative for structural countermeasure to ensure that the rising water levels do not overflow. The length of the dike should be at least $1.5 \mathrm{~km}$ from the beginning (base point) of the dike near the bridge to the downstream area to ensure that the paddy fields are not flooded.

$>$ Riverbed sediments should be dredged to ensure that the river can be functioned optimally.

Stone gabions should be installed along the river banks in vulnerable area which mostly prone to erosion by river floods.

$>$ The leafless hills on the upstream part of the river should be reforested.

\section{REFERENCES}

[1]. Waskito, Tri Nugroho, "Evaluasi pengendalian banjir Sungai Cibeet Kabupaten Bekasi", 2012.

[2]. Muin, Sisi Febriyanti, et al. "Pemodelan Banjir dan Analisis Kerugian Akibat Bencana Banjir di DAS Citarum Hulu", 2015

[3]. Anonim, 2008, "HEC-RAS River Analysis System: User's Manual, US Army Corps of Engineers, Hydrologic Engineering Centre. ASCE", Hydrology Handbook, ASCE, USA. 1986

[4]. Sri Harto Br, "Hidrologi : Teori, Masalah, Penyelesaian", Nafiri Offset, Yogyakarta. 2000

[5]. Sri Harto Br, "Analisis Hidrologi, Gramedia Pustaka Utama”, Jakarta. 1993 